УДК 741.021 .2

\title{
ГРАВЮРА: ІСТОРИЧНИЙ ОГЛЯД І ОСНОВНІ РІЗНОВИДИ МИСТЕЦЬКОÏ ТЕХНІКИ
}

๑ В. М. Іванов-Ахметов, доцент, НТУУ “КПІ», Київ, Україна

Дано определение гравюры и рассмотрены различные виды данной художественной техники. Проанализированы историческое развитие техники гравюры и творческие достижения зарубежных и отечественных художниковмастеров.

The definition prints and also different types of art techniques. Analysis of the historical development of engineering prints and creative achievements of foreign and domestic artists and craftsmen.

Гравюра, як і рисунок, відносяться до одного і того ж розділу образотворчого мистецтва, що носить назву «графіка» (від грецького «графо», що означає «пишу», «рисую»). Сама назва показує, як багато спільного між письмом і рисунком. Авжеж, художник рисуе на папері часто тим самим, чим пише, - пером, олівцем. Та ж, основним виразовим засобом графіки є не живописне багатство кольору, а лінія, штрих.

У графіці завжди важить площина аркуша паперу. На неї вільно лягають лінії рисунка, слухняно слідуючи польотові думки художника. Недаремно в графіці так часто говорять про індивідуальний почерк, про неповторну своєрідність манери вираження.

Проте основна відмінність між гравюрою і рисунком полягає в тому, що гравер не рисує просто на папері, а наносить зображення спочатку на яку-не- будь тверду поверхню, а потім 3 неї вже переносить зображення на папір.

Гравюрою називають відбиток на папері, отриманий з обробленої особливим чином друкарської дошки. Друкарською дошкою можуть правити і дерев'яна дощечка, і металева пластинка, і гладкий камінь. Залежно від матеріалу і способу його обробки розрізняють різні види, або техніки, гравюри: офорт, літографію, ксилографію і так далі. Але сама по собі дошка має лише підсобне значення: метою художника $є$ відтиск на папері - відбиток або, як його іноді називають, естамп. Правда, естампом вважається не всякий відтиск, а лише той, який надруковано під безпосереднім наглядом автора і він має не прикладний, ілюстративний, а самостійний, як прийнято говорити, станковий характер.

Але ж чому художник-гравер виконує складну і трудомістку 


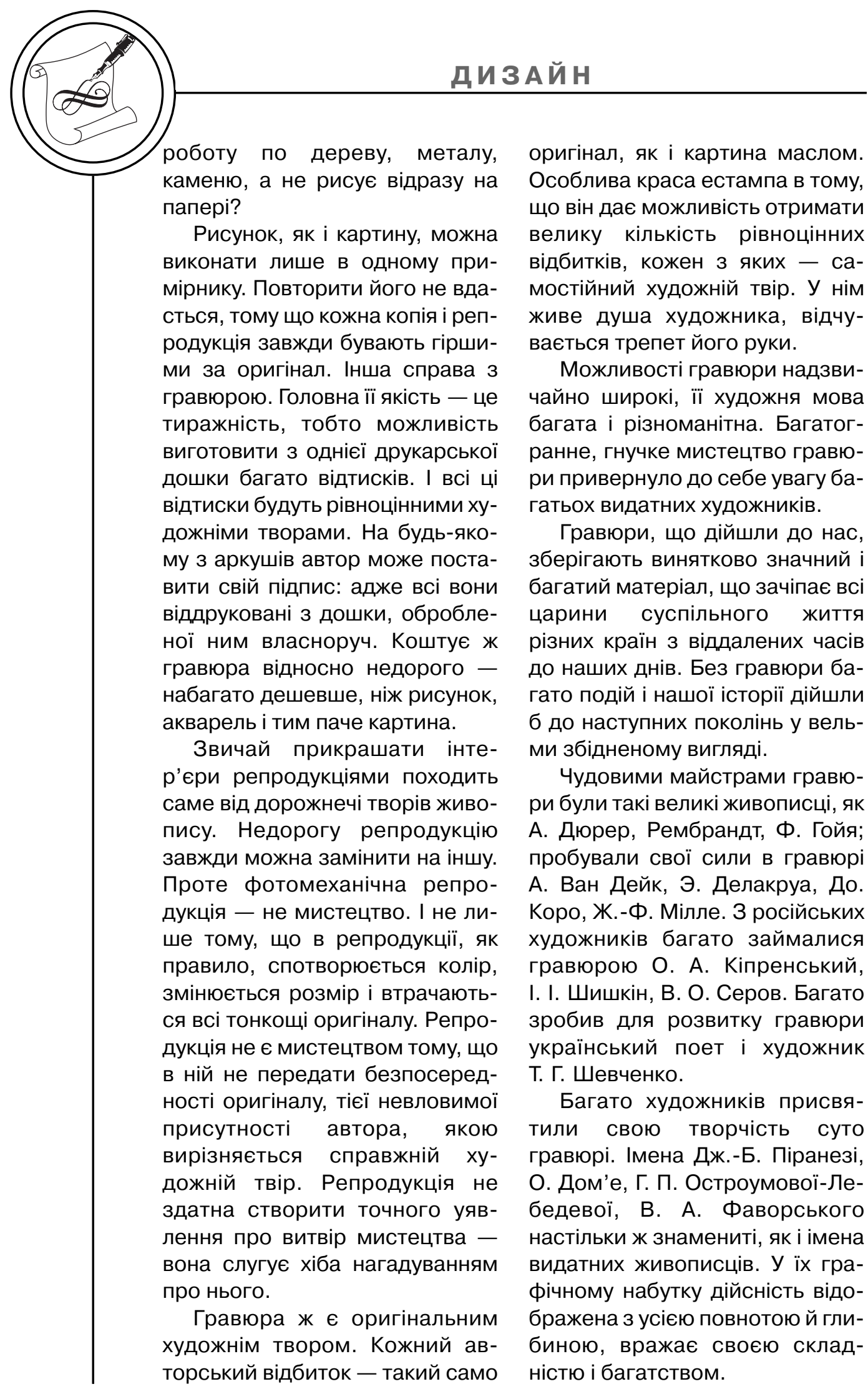


Витоки російського і українського гравірування сягають углиб століть. Стародавнім ювелірам уже була відома техніка нанесення зображень на метал. По суті, це й було справжнє гравірування, ще не призначене для друку і тиражування, але підпорядковане тим само вимогам, що й гравірування звичайне (в його теперішньому розумінні).

Композиція, призначувана митцями для переносу на метал, зазнавала поступові зміни в сенсі строгості і стриманості в засобах виразу. Вона набула більшої конструктивної ясності, лаконічності, простоту i, разом 3 тим, зберегла виразність задуманого образу.

Яскравим і наочним прикладом раннього гравірування на металі може правити зображення на так званих царських брамaх із зібрань Державного Російського музею. Судячи з палеографічних даних, ці брами датують серединою XIV століття і відносять до Володимиро-Суздальському осередка російської художньою культури ${ }^{1}$.

Майстер або цілий колектив, що створив це чудовий художній твір, вигравірував на червоній міді весь рисунок своєї композиції. Для більшої наочності і виразності поглиблені місця на міді були заповнені золотом. Ця робота стародавнього художника і гравера дійшла до нас і вражає своєю високою художньою якістю.

Гравюра з'явилася у Європі відносно нещодавно - в XV столітті. Порівняно, скажімо, із фрескою або мозаїкою, що існують тисячоліття, це зовсім молоде мистецтво. Проте значення ії від цього анітрохи не менше. Жодне мистецтво так хутко не зуміло стати настільки масовим, настільки поширеним, настільки близьким найширшим верствам населення. Недорогі гравіровані аркуші скрашували трудовому людові побут, прикрашали житло. Для неписьменних вони замінювали книги: у яскравих картинках, що добре запам'ятовуються, розкривався зміст цікавих і повчальних історій, повідомлялися різного роду новини.

Утім, найстародавнішою технікою гравюри є гравюра на дереві, або ксилографія. Назва ії походить від грецького слова «ксилон», що означає «дерев'яна дощечка». Ще в IV столітті була відома так звана набійка - друкування кольорових візерунків на тканинах. Набійка - попередниця ксилографії - була поширена в народному мистецтві протягом багатьох століть.

Перші зразки ксилографії з'явилися на Сході ще у VIII столітті. У Європі ж перший відбиток з дерев'яної дошки на папері було зроблено, вочевидь, у кінці XIV століття.

Ця старовинна ксилографія називається обріз: вона виконується на дошці з поздовжнім розпилом. Для обрізної ксилографії використовуються дошки м'яких порід дерева, головним

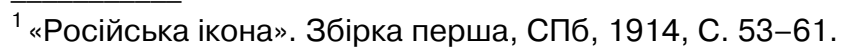




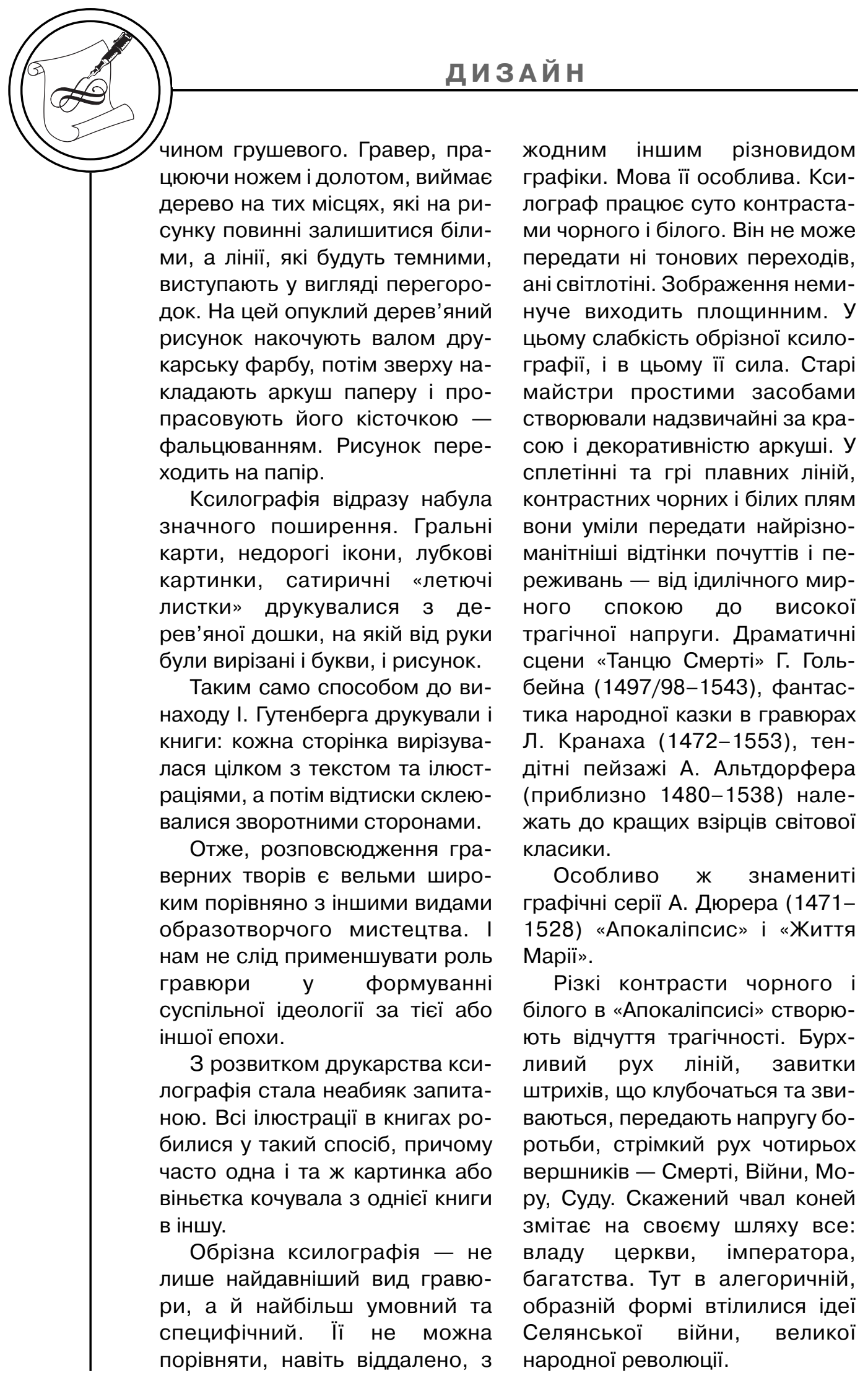


Аркуші з серії «Життя Марії» пронизані м'якістю і ліризмом. Вони сріблясті і легкі, їх лінії плавні й складаються в красивий орнаментальний узор.

Італійській гравюрі на дереві XVI століття, на відміну від демократичного, могутнього, інколи грубуватого мистецтва німецьких майстрів, притаманні більша вишуканість і декоративність. Саме у Італії на початку XVI століття було винайдено техніку кольорової гравюри на дереві.

Думка про використання кольору задля більшої виразності гравюри виникла майже одночасно 3 появою самої гравюри. Народні лубки досі приваблюють яскравою барвистістю. Проте друкувався лише контур, а розфарбовували відбитки від руки.

У 1516 році італійський гравер Уго да Карпі (приблизно 1480-1532) отримав у венеціанському сенаті привілей на винайдений ним спосіб кольорового друку, який був названий к'яроскуро, тобто світлотінь. Уго да Карпі друкував свої гравюри з трьох дощок різного кольору. Він не користувався контуром і не застосовував різко контрастних кольорів, але його аркуші створювали враження справжньої світлотіні, м'яких переходів тону. Уго да Карпі створив ряд аркушів, дивовижних за тонкощами нюансів і гармонією кольорів.

На початку XVII століття кольорова ксилографія 3'являється в країнах Далекого Сходу. Розквіт японської кольорової ксилографії відноситься до XVIII-початку XIX століття. Натоді творили такі чудові майстри, як Харунобу (1724/251770), Утамаро (1753-1806), Хокусай (1760-1849), Хіросіге (1797-1858), Сяраку (працював в 1794-1795 роках), чия творчість неабияк уплинула на європейське мистецтво.

Японська кольорова гравюра на дереві дещо відрізняється від китайської, хоча у них і багато спільного та виготовляється вона тим само способом. У роботі беруть участь три людини: автор рисунка, різьбяр і друкар. Але метою ї̈ $€$ не відтворення живопису, а створення самостійного оригінального твору. Тому різьбяр і друкар користуються значною свободою: друкар, наприклад, може сам добирати кольори, позначені автором рисунка лише назагал (рисунок, як правило, виконується контуром на прозорому папері, який потім приклеюють до дошки).

Головне завдання японського художника полягає в тому, щоб передати певний емоційний стан, настрої радості, печалі або легкого ліричного смутку. Звідси - позірна одноманітність сюжетів японської ксилографії. У одному і тому ж сюжеті - пейзажі або театральній сцені - художники уміли передати нескінченну різноманітність настроїв, уловити миттєвий стан людської душі. Гравюри схожі на японські вірші, такі ж тонкі та витонченні.

Художник у Японії не женеться за зовнішньою прав- 
доподібністю: море у нього може бути зеленим, а небо вночі білим. Але це порушення природного кольору предметів не довільне або випадкове, воно визначається цілою низкою закономірностей, серед яких i японське традиційне ставлення до кольору, і гостре відчуття музичності співвідношень кольору, і суворий художній розрахунок, що враховує виразові можливості різних комбінацій кольорів.

Таким чином, послуговуючись гармонією або контрастом кольорових поєднань, японський художник міг передавати не лише відчуття і настрої, а й людські характери. Жіночі образи з серії «Великі голови» Утамаро, що відрізняються благородством, стриманою гордістю і витонченою простотою, побудовані на гармонійних поєднаннях м'яких спокійних тонів. Навпаки, гравюри Сяраку, що зображають акторів, головним чином у ролях лиходіїв, $€$ різко контрастні. Обличчя актора, спотворене умовною гримасою люті, як світла пляма виступає на темному мерехтливому тлі (яке надруковано не фарбою, а слюдяним порошком). Різкі контрасти глибоких похмурих тонів створюють особливу драматичну напругу.

Гравірування, призначене спеціально для друку на папері, бере початок 3 середини XVI століття. Воно було тісно пов'язане з московським друкарством. Але ще до діяльності першодрукаря Івана Федорова до гравюри зверталися для створення прикрас у друкованих книгах.

Блискучим прикладом використання гравюри можна вважати оформлення книги «Апостол», віддрукованої 1564 року в Москві, яке зробили І. Федоров і його найближчі товариші.

Впродовж XVI-XVII століть гравюри на дереві були призначені винятково для церковних книг - як додатковий художній елемент.

У XVII столітті 3'являються гравіровані естампи з мідних дощок. Їх поява пов'язана 3 майстрами-срібниками Збройної Палати. Вельми цікаві аркуші 3 «Азбуки» 1692-1694 років, складеної Каріоном Істоміним і гравірованої Леонтієм Буніним. Тут, як ми бачимо, релігійна догма поступається місцем жвавому спостереженню і спілкуванню 3 життям. Ця «Азбука» містить ніби цілу енциклопедію світських знань. Проглядаючи аркуші цього рідкісного видання, історик-мистецтвознавець може сміливо говорити про зародження раннього російського реалізму.

Справжній розквіт гравірування на металі пов'язаний 3 XVIII століттям. У епоху становлення Російської імперії й Петра I гравюра набуває пізнавального й утилітарного призначення, а отже, має й реалістичніший характер, ніж це було, наприклад, у гравюрах XVII століття.

Всі значні події цієї епохи чітко відображені в мистецтві гравюри.

Надалі, при спадкоємцях Петра I, майстри російської гра- 
вюри звернулися винятково до портретів «високих персон» і до тем прославляння монарха та його оточення. Виняток, мабуть, становив хіба розділ видів перспектив Петербургу. В них ні-ні та промайне жваве спостереження художника-гравера за довколишньою дійсністю.

Багато славетних імен дало російське гравірування XVIII століття. Серед них імена О. і І. Зубових, численних перспективістів групи М. І. Махаєва, Е. П. Чемесова, Г. І. Скородумова i інших, які збагатили російську і світову художню культуру, стверджуючи тим самим наявність російської школи гравірування.

В самому кінці XVIII століття російському гравіруванню прищепили досвід в ландшафтнопейзажному жанрі. Це захоплення збіглося зі створенням у стінах Академії мистецтв особливого граверно-ландшафтного класу. У роботах цього класу елементи класицизму поєднувалися $з$ особливостями перспективних романтичних настроїв.

У XVIII столітті остаточно зміцнилося мистецтво гравірування на металі, але ж воно не залишилося однаковим протягом усього свого існування. Якщо гравюра травленням (офорт) панувала в широкому вжитку за перших десятиліть XVIII століття, то надалі офорт поступово здавав свої живописні позиції строгим, розміреним прийомам класичного гравірування різцем. Це мало місце переважно в парадних портретах, покликаних прославляти зображених осіб, що грало значно меншу роль у суворих і ділових за змістом гравюрах епохи Петра I.

Гравірування на дереві, яке застосовували для оформлення книжкової продукції XVIII століття, не було забуте народними майстрами-різьбярами, котрої створювали «народні» аркуші. Зміцненню цього мистецтва сприяли традиції старовинного народного різьблення по дереву (набійні, пряникові дошки і орнаментування предметів побуту).

Як уже згадано, старі майстри працювали на дошці дерева з поздовжнім розпилом. Ця робота важка: волокна дерева чинять опір ножеві. I от наприкінці XVIII століття англійський гравер Томас Б'юїк (1753-1828) винайшов новий спосіб гравірування - на поперечному зрізі стовбура, так звану гравюру торця. Б'юїк брав не грушеве дерево, як раніше, а твердіші його сорти. Стовбур дерева (бук, пальма, самшит) зрізається впоперек волокон і, оскільки у цих дерев стовбур тонкий, то, щоб отримати велику дошку, склеюють декілька маленьких, ретельно підганяють їх одна до одної і полірують. Працюють на такій дошці різцем, добиваючись не просто контрастів чорного і білого, а поступових переходів від темного до світлого. Рисунок при такій роботі виходить чіткий і тонкий, видно кожен найдрібніший штрих. Дрібні штрихи створюють об'єм, сітка білих штрихів 


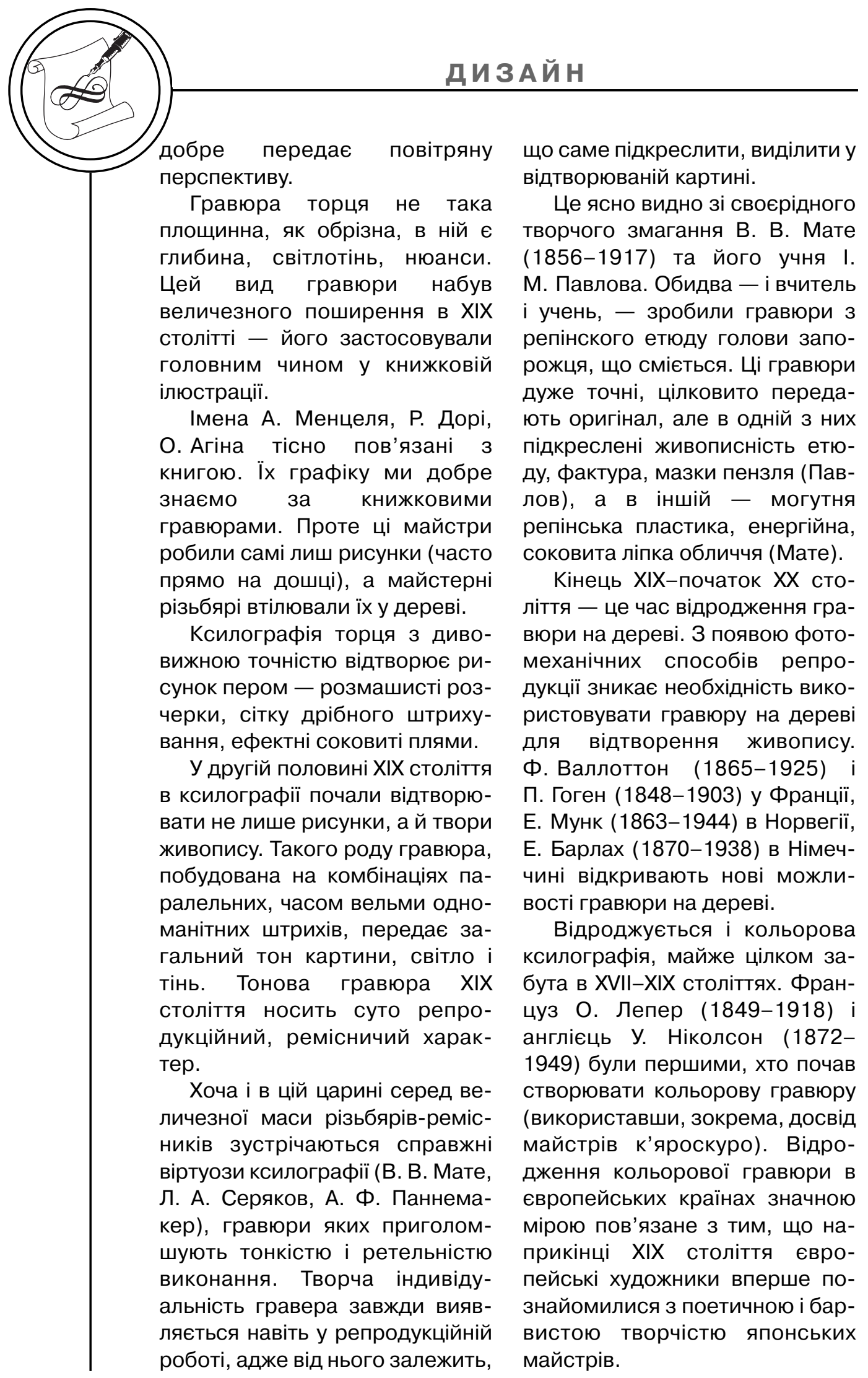


Сучасні художники також роблять і обрізну й торцеву ксилографію. Оскільки головні виразні засоби гравюри на дереві - це пляма і лінія, то, на перший погляд, техніка неначе примітивна. Проте, коли розглядаєш підряд аркуші гравюри на дереві, то вражає різноманітність прийомів, якими користуються ксилографи. М'які, майже невловимі переходи кольору в гравюрах Лепера змушують пригадати японських майстрів XVIII століття. Ніколсон заливає суцільними контрастними кольорами великі, чітко розмежовані площини. Лаконічні, вкрай узагальнені гравюри Валлоттона цілком побудовані на контрастному зіставленні плоских чорних і білих плям. Навпаки, в гравюрах Барлаха, який був скульптором, ми відчуваємо прагнення розпушити, зруйнувати площину. Залежно від теми, від поставленого завдання, ксилограф шукає нової виразності, нового виразного прийому. I ми бачимо, як оживає аркуш паперу, 3 якою точністю і гостротою передає на ньому художник і оксамитову чорноту ночі, і блищання снігу, рух і мигтіння вуличного натовпу. Начебто примітивна техніка виявляється нескінченно гнучкою. Недаремно ксилографія улюблена техніка сучасності.

у творчості визначних майстрів сучасності відроджується колишня роль ксилографії як найбільш демократичного і масового виду мистецтва. Характерно, що художники звертаються до майже забутої техніки старих майстрів обрізної гравюри. Відмовляючись від наслідування живопису, вони прагнуть виявити специфіку ксилографії, використовувати її яскраву і гостру мову.

Німецька художниця Кете Кольвіц (1867-1945) присвятила своє мистецтво життю і боротьбі. Ї̈̈ гравюри з серії «Війна» звучать могутнім протестом проти найстрашнішого народного лиха. Глибоке горе, відчай, обурення безглуздою жорстокістю - все це передано художницею з дивовижною силою і величезним людським болем.

Творчість Франса Мазереля (1889-1972) тісно пов'язана 3 найгострішими питаннями сучасності. Вона переросла рамки національної школи, стала інтернаціональною. Художникгромадянин Мазерель свідомо поставив своє мистецтво на службу визвольній боротьбі людства. Його гравюри чіткі i ясні, їх зміст відразу доходить до глядача, вони схожі на маленькі чорно-білі плакати. Мазерель говорить на весь голос, не лишаючи нічого неясного.

Свої гравюри Мазерель зазвичай видавав у вигляді серій книжок, так званих романів у картинках. Гравюри в цих книжках об'єднані загальним сюжетом або ідеєю. Тексту в них немає.

Подібна форма використання графіки, придумана Мазерелем, розширює можливості гравюри, дозволяє показати розвиток сюжету в часі. Історія молодого робітника, що знаходить свій шлях у класовій боротьбі, 
життя сучасної людини, яка шукає і не знаходить щастя і правди в джунглях великого міста, революційна ідея, яка освітлює своїм сяйвом всі сторони сучасного життя, - ось сюжети цих книжок, глибоко народних за задумом, простих і вражаючих за виконанням.

При всій відмінності індивідуальної манери Кольвіца і Мазереля у них $є$ одна загальна риса - прагнення спростити форму, уможливити її ясність і лаконічність. Узагальнені силуети, осягнення всього аркуша в цілому, деяка грубуватість штриха все це дозволяє говорити про своєрідну переробку в їхній творчості традицій народної графіки.

Натомість ксилографії росіянина В. Д. Фалілєєва (18791948) побудовані на гострих романтичних контрастах кольору. Він досить рано відійшов від ксилографії, звернувшись до гравюри на лінолеумі як до техніки, що більше відповідає його монументально-декоративним завданням.

Почесне місце в створенні російської кольорової гравюри належить Г. П. Остроумовій-Лебедєвій (1871-1955). ї̈̈ гравюри відрізняються дивовижною гармонією, тонкістю і музичністю.

3 поетичним ліризмом передає художниця своєрідну красу Санки-Петербурга: строгу архітектуру, блиск і прозорість води каналів, бліде північне освітлення. ї̈̈ гравюри вишукані за кольором, в них неабиякий талант живописця поєднується 3 високою майстерністю графіка, який вільно володіє всіма виразними елементами ксилографії. Лаконізм, прекрасне використання білого аркуша паперу, який художниця уміє організувати небагатьма точно знайденими штрихами, стримане і благородне поєднання плям кольору - головні художні прийоми Остроумової-Лебедєвої. 3 їх допомогою вона створює особливу поетичну атмосферу, відтворює не зовнішній вигляд міста, а той поетичний настрій, який воно у нас викликає. Остроумова-Лебедєва - учениця Мате. Проте в ії творчості немає нічого від тонової репродукційної ксилографії XIX століття.

Традиції Мате були продовжені і підхоплені іншим його російським учнем - І. М. Павловим (1872-1951). Стара Москва з її кривими провулками, маленькими будиночками, бруківкою зараз майже зникла. Зовнішність столиці змінилася невпізнанно. Гравюри Павлова назавжди зберегли Москву, якою вона була більш як півстоліття тому. 3 об'єктивністю історика він рисує і старовинні церкви, і живописні московські куточки: дворики, занесені снігом, тихі вулиці. Техніка тонової гравюри, в якій працював Павлов, добре передає поступові світлотіньові переходи, різні подробиці, що наділяють зображення особливою достовірністю.

Проте головні досягнення російської і української ксилографії пов'язані передовсім 3 книгою. Ми по праву можемо 
пишатися нашою школою ксилографів-ілюстраторів, яка сформувалася ще в 1920-1930-ті роки, - це одне з найбільших явищ у сучасному мистецтві. Майстри гравюри розглядали книгу як єдиний художній організм. Вони робили не тільки, ілюстрації, але продумували всі елементи оформлення: палітурку, суперобкладинку, заставки та інші прикраси. Формат книги, розташування ілюстрації на аркуші, вибір (а іноді й створення) шрифту - все це було справою художників. Головна мета їх роботи - відповідність зовнішнього вигляду книги стилю і характеру літературного твору. В результаті виникали справжні шедеври книжкового мистецтва, в яких органічно поєднувалися всі елементи графічного оформлення, а задум автора проступав особливо чітко і яскраво.

Гравюра на дереві з її чорними штрихами чудово поєднується з шрифтом, причому для художника тут відкривається безмежне поле діяльності: чорний жирний шрифт можна поєднувати 3 легкою тоновою гравюрою або світліший і тонший шрифт - з гравюрою інтенсивною й контрастною.

Початкове десятиліття XIX століття було відзначене героїчними подіями Вітчизняної війни 1812-1815 років. Події Вітчизняної війни не могли не відбитися на російському образотворчому мистецтві, у тому числі і на гравюрі. У ці роки, поряд з існуванням гравюри на дереві і металі, з'явився новий вид граверно-друкарської техніки - літографія. Завдяки простоті використання, вона швидко завоювала увагу і симпатії до себе в середовищі російських художників, ставши на два-три десятиліття найулюбленішим і найпоширенішим різновидом їх граверної практики. Особливо блискучі досягнення в області літографії ми бачимо в роботах художників-романтиків і ранніх реалістів (О. Й. Орловського, О. А. Кипренського, С. Ф. Галактіонова та ін.), що відтворювали літографським способом види Петербурга і міст Росії, портрети і жанри.

Гравірування на металі в першу половину XIX століття відбувалося двома способами: класичне гравірування різцем як наступник старої лінії Академії Мистецтв (М. І. Уткін і його школа) і офорт. Цьому останньому різновиду приділили увагу багато видатних діячів Академії Мистецтв від О. Е. Егорова до О.А. Кипренського й К. П. Брюллова включно, хоча самостійного місця в їхній творчості офорт не посів.

У цю епоху, завдяки розвитку друкарсько-видавничої діяльності в Російській імперії відродилося і гравірування на дереві. Воно було застосоване головним чином для виконання ілюстрацій до книг і журналів. Цей вид гравірування привертає до себе увагу художниківреалістів. Художник, враховуючи подальшу працю гравера, рисував потрібну композицію на дошці. Гравер, слідуючи нанесеному на дошці рисунку, вирізав його. Найчудовішим 
пам'ятником подібного гравірування на дереві $\epsilon$ ілюстрації до «Мертвих душ» М. В. Гоголя, виконані гравером Е. Е. Бернардським за рисунками О. О. Агіна.

Середина XIX століття, позначена небувалим підйомом суспільної самосвідомості, завдяки широкій хвилі прогресивних ідей революційної демократії (Белінського, Чернишевського, Добролюбова), дала чудові зразки гравюри. Серед них реалістичні твори Т. Г. Шевченка - вихідця 3 кріпаків, що він пережив багато сумного i важкого в умовах тодішньої російської дійсності. Традиції Шевченка розвивали його однодумці, подібно до Л. М. Жемчужникова.

У 1871 році російські художники створили «Товариство росіян аквафортистів». До нього увійшло все основне ядро художників-реалістів майбутнього Товариства пересувних художніх виставок - від І. Н. Крамського до І. І. Шишкіна. Це Товариство проіснувало три-чотири роки не могло мати вирішального впливу на школу російського гравірування, але заслуги його діячів забути не можна. Там працювали з любов'ю і інтересом І. М. Крамськой, М. М. Ге, К. А. Савицький, В. М. Максимов та інші. Особливо багато і поглиблено трудився І. І. Шишкін, який був не тільки живописцем, а й професіоналом-гравером.

Незалежно від петербурзького «Товариства росіян аквафортистів», російські пансіонери в Парижі на чолі 3
I. Е. Репіним також почали займатися в ці роки офортом, вважаючи, що оволодіння новою технікою дасть їм можливість активніше поширювати свої твори. Але їх насамперед захоплювали заняття живописом, тож багаті можливості гравюри не були ними використані повною мірою.

Швидко зростав інтерес до мистецтва гравюри і в Москві. В. Г. Перов створив ряд вражаючих літографій. Пізніше там поглиблено займався офортом В. Е. Маковський - учень в цій галузі Л. М. Жемчужникова. Літографські роботи, пройняті великими суспільними ідеями, були створені В. А. Симовим («Важке прохання»), С. В. Івановим («Переселенці»), П. І. Коровіним («Обробка поля»), А. К. Сильверсаном («Весна»). Всі ці роботи відносяться до 90-х років XIX століття.

Гравюра на дереві в цю епоху, з легкої руки Л. А. Серякова та його учня і наступника В. В. Мате, вирішувала нове завдання. Нова гравюра прагнула розширити свої технічні можливості у бік збагачення своєї природи тоном і пластичністю. Граверам вдавалося передати складні тонові переходи і тим збагатити вітчизняну поліграфію на більш надійний спосіб відтворення зразків живопису.

Одним з чудових граверів, які пройшли цю школу тонової гравюри, був академік I. М. Павлов. Завдяки його граверним роботам російське суспільство ознайомлювалося 3 шедеврами реалістичного живопису 
І. Е. Репіна, В.І. Сурикова, В. М. Васнецова, В. Е. Маковського і ін.

Тоді ж у Петербурзькій академії мистецтв після впровадження нового статуту (1893), коли до керівництва вищої художньої школи були запрошені видатні художникипередвижники, відроджується інтерес до гравюри. Створюється графічна майстерня (за старою, але забутою академічною традицією) під керівництвом В. В. Мате.

Але цей новий етап в історії розвитку російського гравірування істотно відрізнявся від попереднього. Висока ідейність раннього передвижництва до цього часу підупала. На зміну відчуттям громадянськості в мистецтво проникали інші настрої, що значно підсилили позиції естетизму.

Але реалістичне мистецтво гравюри продовжувало жити, існувати і розвиватися. Неабияку роль в цій справі відіграв В. В. Мате, котрий умів об'єднувати довкола себе жваві, творчі сили не лише своїх безпосередніх учнів, а й таких відомих художників, як І. Е. Репін, В. О. Серов, І. І. Левітан та інші. Тільки за цих умов могли 3'явитися чудові роботи В. О. Серова в офорті і літографії, Г. П. ОстроумовоїЛебедєвої - в гравюрі на дереві. 3 останнім ім'ям пов'язане відкриття кольорової гравюри в Росії. В майстерні Мате працювали такі майстри гравюри, як М. Герардов, Л. Овсянников, А. П'ятиго- ристий,

B.

Фалілєєв,

П. Шиллінговський та інші.

Провідним майстром книжкової гравюри став В. А. Фаворський (1886-1964). Десятки книг прикрашені його чудовими гравюрами. I кожен твір він ілюстрував по-різному, слідуючи не лише текстові, а й стилю.

Для книги А. Франса «Судження абата Жерома Куан'яра» художник зробив заголовну буквицю з фігурками, відродивши старовинну традицію прикрашеного алфавіту. Але самі ці буквиці зовсім не стилізовані: фігурки живі, об'ємні, вміщені в просторове середовище, організоване і підкреслене строгим рисунком літер.

Графічні прийоми Фаворського на диво різноманітні. 3 однаковою віртуозністю він володіє плямою, силуетом, контуром, білим штрихом. Рівне, паралельне штрихування надає його гравюрам м'якого сріблястого колориту, енергійні розчерки дають їм динаміку. У гравюрах Фаворського особливо цінні пластичність форми, об'єм і простір, передані простими засобами, що не порушують площини аркуша. Подібні поєднання об'єму і площини ми зустрічаємо на фресках староруських майстрів.

«Будиночок у Коломні» О. С. Пушкіна Фаворський ілюструє зовсім в іншій манері. Широкі білі поля поцятковані маленькими легкими гравюрками. Вони наче кружляють навколо колонок тексту, нагадуючи невимушені рисунки поета на полях чернеток. Тут і побіжні 


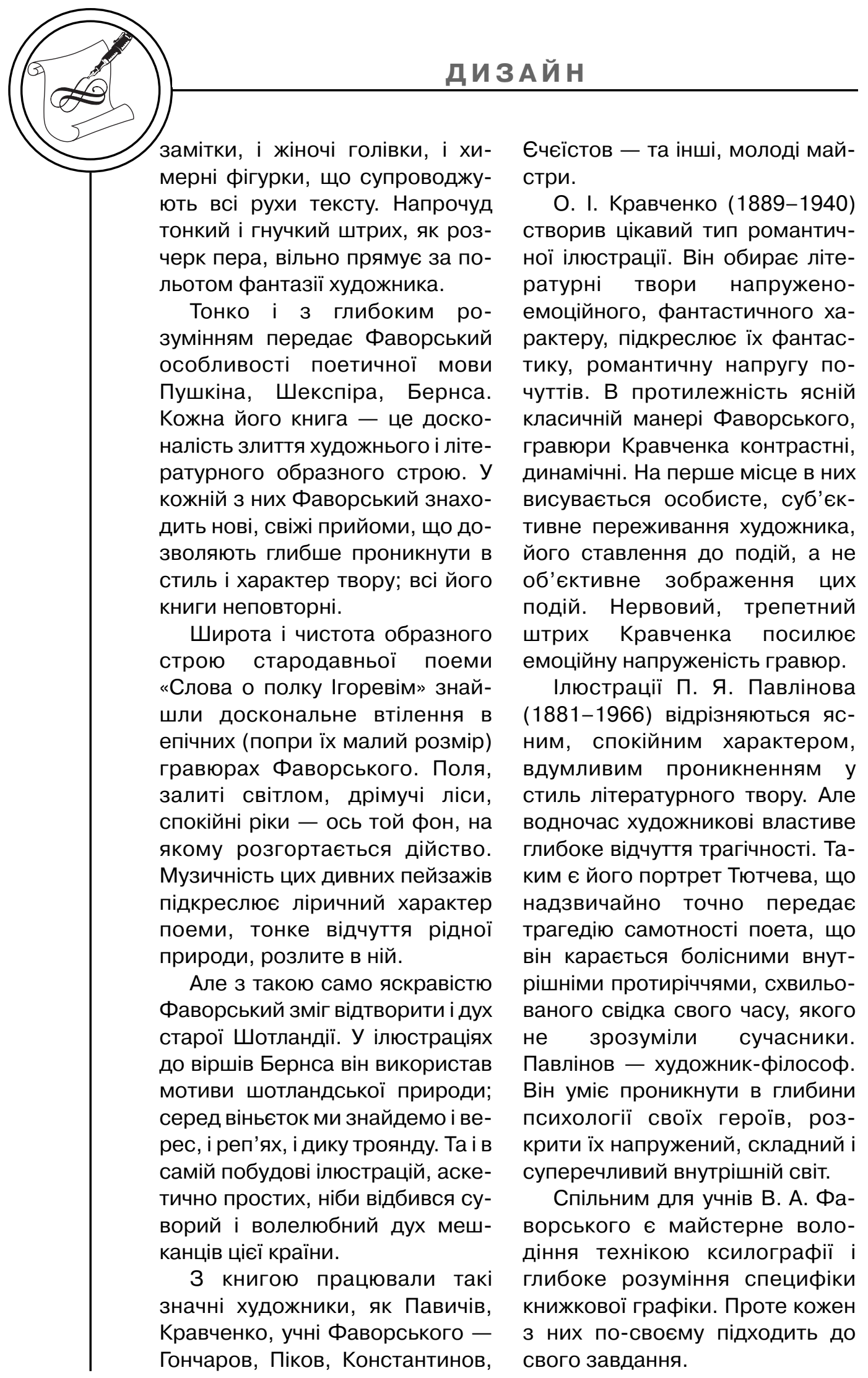


Ілюстрації М. І. Пікова (1903-1973) карбовано-строгі, вони добре пов'язані з площиною сторінки і з шрифтом, дещо стилізовані. Піков любить метафору, тонку орнаментику, витончену і розумну гру ліній.

Г. О. Єчєїстов (1897-1946) гостро, різко, майже гротескно передає неспокійний дух поезії Генріха Гейне. Його ілюстрації до поем «Німеччина. Зимова казка» і «Атта Троль» - рідкісний зразок цілковитого збігу темпераменту художника і поета.

Ілюстрації Ф. Д. Константинова (1910-1997) до «Кентерберійських оповідань» Дж. Чосера підкреслюють грубувату жанровість тексту, неповторну характерність типів. Його цікавлять характер, своєрідність ситуації, історична обстановка.

Творчість А. Д. Гончарова (1903-1979) відрізняється емоційністю. Його соковиті гравюри побудовані на м'яких живописних контрастах; у них навіть тоді, коли художник користується лише чорним і білим, точно передано відчуття кольору.

Яскравий живописний дар Гончаров поєднує з глибоким розумінням специфічних особливостей саме книжкової графіки. Його ілюстрації тісно пов'язані з текстом, виділяють в ньому найсуттєвіше, відзначають ключові моменти розвитку сюжету. Його персонажі дані в конкретному середовищі, у тісній взаємодії і з нею, і один 3 одним.

В. В. Домогацький (19091986) В ілюстраціях до Тур- генєва зумів передати м'якість манери і поетичну атмосферу його романів. Любов'ю до рідної природи, до російської старовини пройнята творчість М. С. Чуракової (1924-1982). у ії гравюрах тонко втілений глибокий зв'язок людини з природою.

До художників, що продовжують традиції класичної книжкової ксилографії, належить також Д. С. Бісті (1925-1990). Композиції Бісті побудовані на різких контрастах, на просторових зсувах. Він широко користується метафорою, в композиції книги застосовує лейтмотиви і пластичні співзвуччя, що перебувають у взаємодії з текстом, але не притримуються його з буквальною точністю. Художник швидше надає свої роздуми на теми, дані письменником.

Цікава гравюра на дереві середньоазіатських графіків Л. О. Ілліної (1915-1994) і Е. М. Сідоркіна (1930-1982), що зробили великий внесок до розвитку графіки Киргизії і Казахстану.

Природно, що майстрикнижники займаються майже винятково чорно-білою гравюрою. Проте це не означає, що їх не цікавить колір.

у 1932 році було задумано ювілейне видання вірменського народного епосу «Давид Сасунський». До участі в цій роботі була залучена група учнів Фаворського - М. Піков, М. Фаворский та інші. У цій книзі поряд 3 чорно-білими ілюстраціями була ціла низка кольорових гравюр - фронтиспис, 
розвороти та інші. Колір тут, дуже красивий, вишукано-акварельний, грав декоративну роль, надаючи ілюстраціям ошатної святковості.

Інший підхід до кольору ми бачимо в творчості М. І. Полякова (1903-1978). Цьому художникові належить цілий ряд мініатюрних рукописних книжечок, прикрашених гравюрами. Твори Ронсара, Дю Белі, середньовічної поезії надихнули художника на своєрідний стиль ілюстрації: витончені чорно-білі гравюрки ретельно розфарбовані, підсвічені сріблом, на зразок мініатюр з рукописів середньовіччя і раннього Відродження.

У гравюрах Г. Д. Епіфанова (1900-1985) до «Повчальних новел» Сервантеса колір надається як загальний тон, як вишукано нюансована акварельна заливка, на якій чітко проступають чорні контури фігур. Художник широко застосовує білий штрих, який додає його аркушам особливу легкість і прозорість.

Шедевром російської книжкової гравюри сталі ілюстрації М. І. Піскарьова (1892-1959) до «Анни Кареніної». Колір для Піскарьова править засобом розкриття внутрішнього драматизму окремих сцен, виразним прийомом, що підкреслює загальну трагічну атмосферу роману. Напливи густого синього, легкого зеленого створюють своєрідний фон для дійства, виявляють його прихований підтекст. Колір органічно входить в образну систему твору.
Кольорова ксилографія країн СНД відрізняється винятковою різноманітністю прийомів. Тут і класична манера друку 3 декількох дощок, коли при накладенні їх одна на одну виникають нові кольори, і нові прийоми друку рідкою фарбою. Іноді дається лише загальний тон, а контур друкують чорним або навіть залишають білим тощо.

Але ксилографія майстрів згаданої школи - це не лише книжкова гравюра. Багато художників працюють в царині естампа, досягнувши тут оригінальних і цікавих результатів. Якщо в книзі застосовують ксилографію торця, то майстри естампа звертаються частіше до гравюри обрізу.

Литовські художники створюють свої гравюри у дусі народного лубка, дотримуючись вірності традиції як в сюжетах, так і в техніці. Гравюри на сюжети литовських народних пісень А. Макунайте (народ. 1926) нагадують дерев'яне різьблення, старовинні лубкові картинки, орнаменти вишивок. Вони зумисне грубуваті, але не позбавлені своєрідної витонченості.

Естампи І. В. Голіцина (19282007) відрізняються строгістю і складністю техніки. Художник обирає прості сюжети: натюрморт, портрет в інтер'єрі, якунебудь домашню сцену. Але невибагливість його мотивів оманлива. Голіцин - художникфілософ, який уміє за зовнішньою оболонкою явищ роздивитись їх глибокий духовний зміст. Так, «Натюрморт 3 граверними інструментами» 
звучить урочистим гімном важкій, суворій і радісній праці ксилографа. А портрет В. А. Фаворського з онуком («Вранці у Фаворського») навіює роздуми про зміну поколінь, спадкоємність культури, про внутрішню близькість, що пов'язує рідних по крові та духу людей. Техніка гравюри Голіцина бездоганна. Він вільно користується штрихом, то легким і тонким, то соковитим і насиченим. Його аркушам притаманні м'якість і тональне багатство, легкий сріблястий колорит, якого важко досягнути в обрізній ксилографії.

У XX столітті набула великого поширення ліногравюра, частково витіснивши ксилографію.

Гравюра на лінолеумі виконується приблизно так само, як гравюра на дереві. Працюють ножем і спеціальним штихелем, що має форму жолобка. Зображення, як і на дерев'яній дошці, опукле, і на відтиску - художній ефект, дуже близький обрізній гравюрі (відсутність півтонів, пляма, чорний штрих на білому папері). Але лінолеум дешевший, ніж дерево, і працювати на ньому значно легше, оскільки він куди податливіший, м'якший i, головне, більш однорідний, ніж найм'якіша дерев'яна дошка. Цим пояснюються широке розповсюдження ліногравюри і популярність її в тих майстрів, котрі прагнуть до актуальності, до швидкого відгуку на події сьогоденності.

у техніці ліногравюри виконана більшість робіт знаменитої Майстерні народної графіки в Мексиці. Група молодих мекси- канських художників заснувала цю майстерню в 1937 році з метою створити мистецтво, що доступне народу, пропагує ідеї прогресу і революції. Боротьба за мир, за національну незалежність, за хліб і свободу - ось теми їх гравюр.

Молоді ентузіасти працювали в складних умовах: не вистачало коштів, паперу. Придбаний ними друкарський верстат був дуже старий. Існує легенда, що на нім друкували свої листівки паризькі комунари. Гравюри доводилося друкувати лише чорно-білими, оскільки не вистачало грошей на фарби.

Роботи очільника майстерні Леопольдо Мендеса (19021969) та інших її членів відрізняються монументальним характером. Лаконічні, прості композиції (зазвичай великого формату), різкі, сильні штрихи чудово передають образи народних героїв і сцени революційної боротьби мас. Роботи Майстерні народної графіки випускалися у вигляді листівок, плакатів і тематичних альбомів. Леопольдо Мендес розширив сферу впливу ліногравюри, зробивши ряд аркушів, призначених служити заставками для прогресивного кінофільму «Ріо Ескондідо». На екрані ці гравюри, збільшені до величезних розмірів, справляють враження напружених і могутніх монументальних рельєфів. У графіці пострадянських країн інтерес до гравюри на лінолеумі пов'язаний передусім зі становленням сучасного естампа. Яскравим зразком в цьому відношенні $€$ творчість П. М. Староносова (1893-1942). 


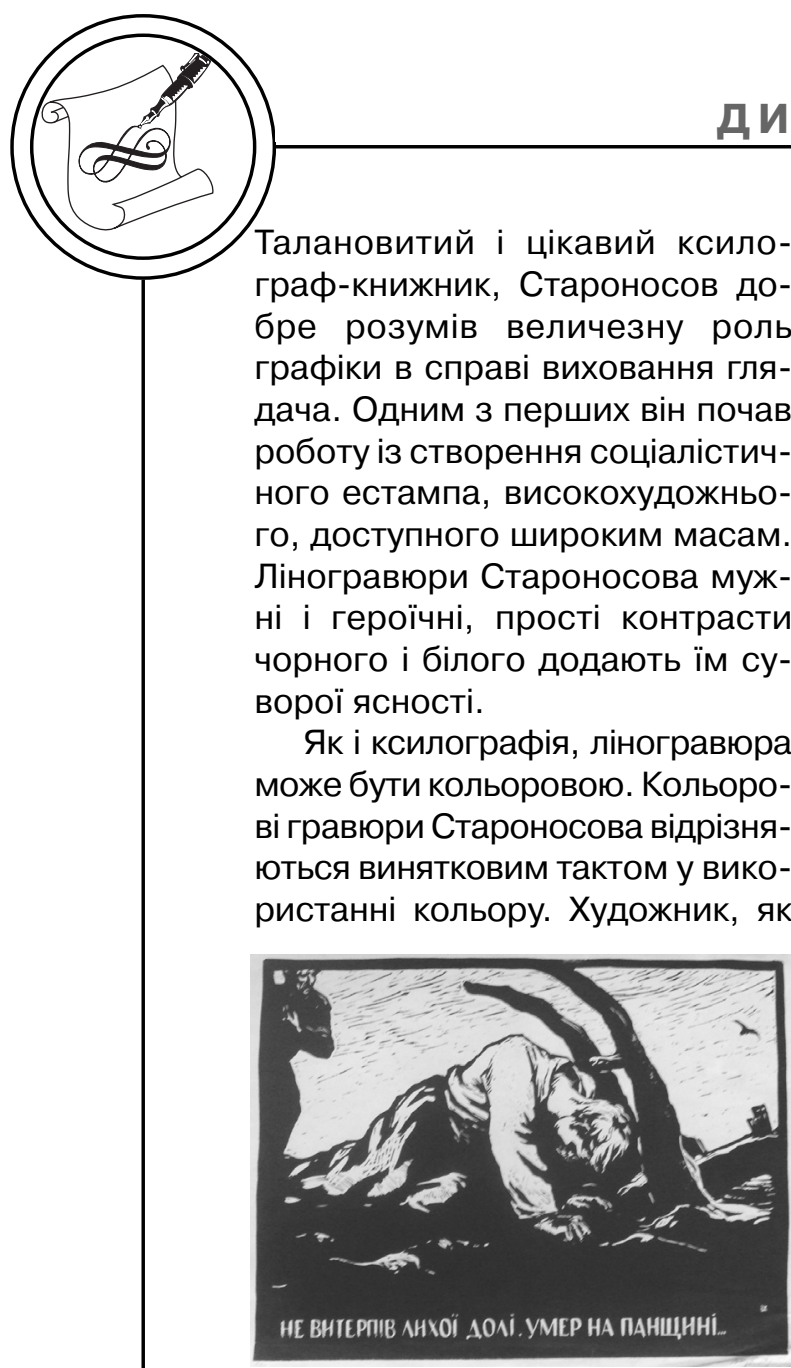

Рис. 1. Куткін Володимир Сергійович, 1926 р. н. Плакат. 39,2×51. Лінорит. 1957 р. Робота виконана в манері повздовжньої обрізної гравюри.

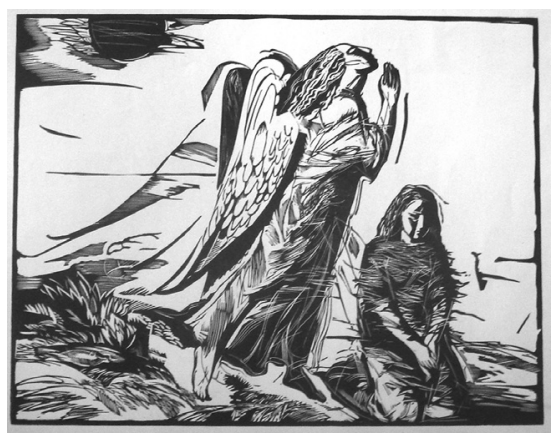

Рис. 2. Миколайчук Наталя Іванівна, 1956 р. н., народний художник України. 36,4×45,2. Лінорит, 1990 р. Робота виконана в манері обрізної гравюри на дереві. правило, застосовує малу кількість дощок, кольором заливаються великі площини, іноді він застосовується як фон, на якому надруковано чорний контур.

Такий колірний лаконізм, крім суто художніх, декоративних ефектів, має і практичне значення: гравюру легко друкувати, дошки витримують великі тиражі. Староносов створив достовірно народний естамп.

Сьогодні ми $€$ свідками розквіту гравюри та їі багатющих досягнень. Але огляд цього матеріалу складає особливий розділ в історії гравюри.

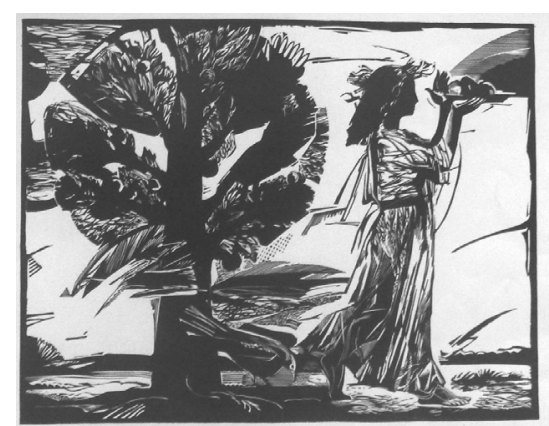

Рис. 3. Миколайчук Наталя Іванівна, 1956 р. н., народний художник України. 35,5×45,4, 1992 р. Імітація обрізної гравюри.

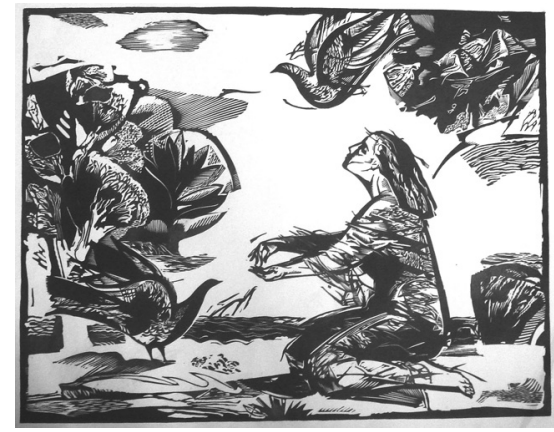

Рис. 4. Миколайчук Наталя Іванівна, 1956 р. н., народний художник України. 35,6×45,4, 1991 р. Лінорит, виконаний в манері обрізної гравюри, на дереві. 


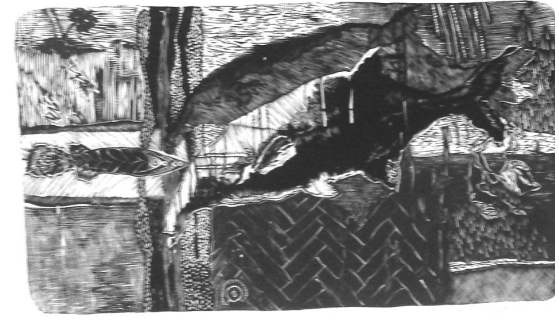

Рис. 5. Сабко Ольга Валеріївна, 1990, «Акваріумна дійсність».

30×17, лінорит, 2013 р. Комбінований лінорит, виконаний в манері торцевої та обрізної гравюри.

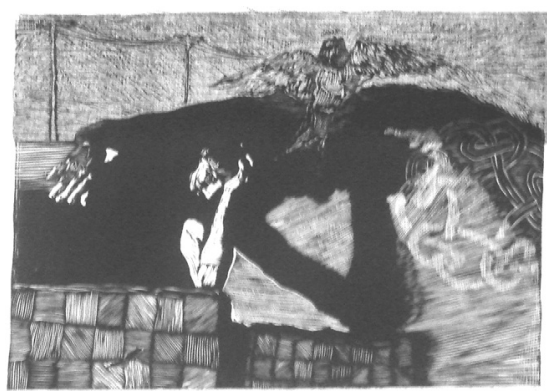

Рис. 6. Сабко Ольга Валеріївна, 1990, «Жахи на Кудлі - I», 32×23,5, лінорит, 2013 р. Виконано в манері торцевої та обрізної гравюри на дереві.

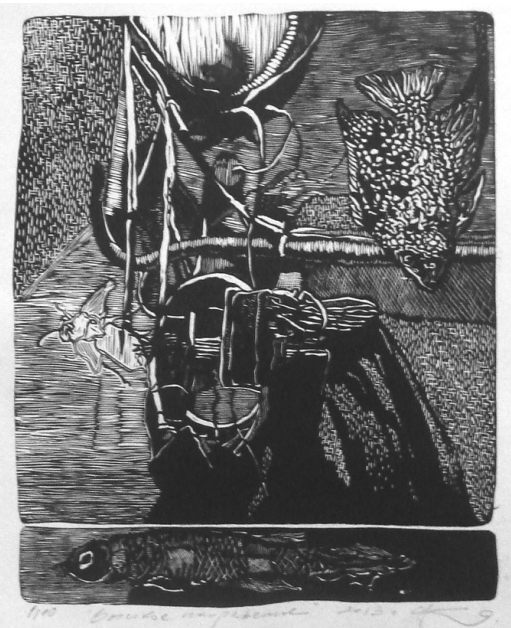

Рис. 7. Сабко Ольга Валеріївна, 1990, «Висока напруга», 16×20, лінорит, 2013 p.

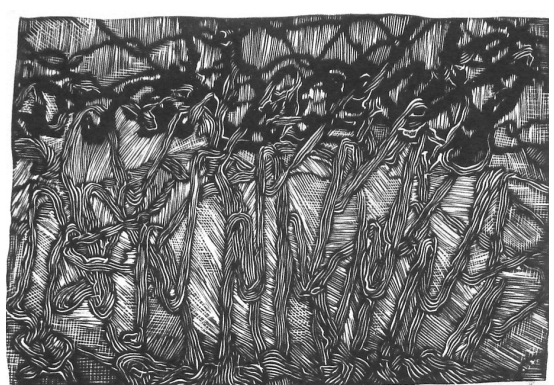

Рис. 8. Сабко Ольга Валеріївна, 1990, «Навіщо все ускладнювати», $10 \times 15$, лінорит, 2013 р. Імітація торцевої гравюри на дереві.

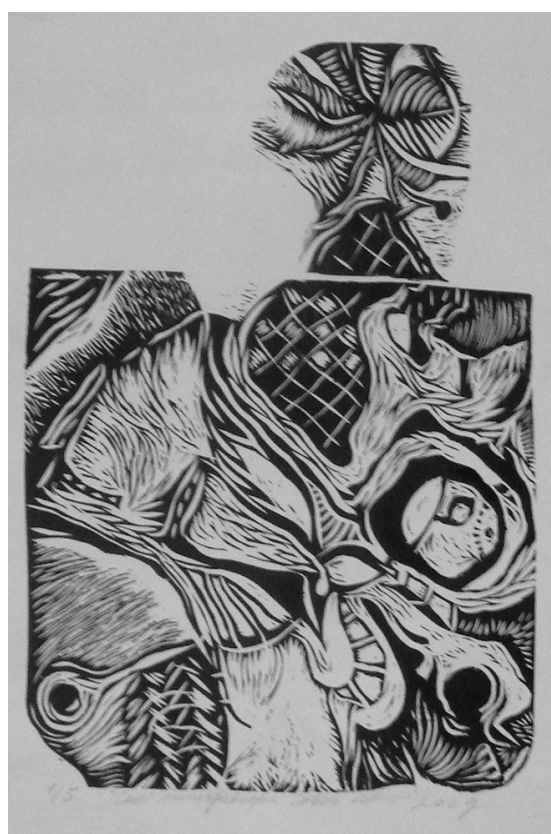

Рис. 9. Сабко Ольга Валеріївна, 1990, «Сон»,20×15, лінорит, 2009 р. Робота виконана як імітація торцевої гравюри на дереві. 
1. Деніке Б. Японська кольорова гравюра / Б. Деніке. - М., 1935. 2. Чегодаєв А. Шляхи розвитку російської радянської книжкової графіки / А. Чегодаєв. - М., 1955. 3. Лівітін Е. Офорти Рембрандта / Е. Лівітін. - М., 1962. 4. Турова В. В. Що таке гравюра / В. В. Турова. - М., 1986.

1. Denike B. Yaponska kolorova hraviura / B. Denike. - M., 1935. 2. Chehodaiev A. Shliakhy rozvytku rosiiskoi radianskoi knyzhkovoi hrafiky / A. Chehodaiev. - M., 1955. 3. Livitin E. Oforty Rembrandta / E. Livitin. - M., 1962. 4. Turova V. V. Shcho take hraviura / V. V. Turova. - M., 1986.

\section{Рецензент - О. М. Левчук, к.філол.н.,} доцент, НТУУ «КП|»

Надійшла до редакції 25.09.13 